\title{
Materialist Premises in Hobbes and Kropotkin for Antipodean Conclusions: The State of War and the Mutual Aid
}

\author{
Francesco Scotognella, PhD \\ Dipartimento di Fisica, Politecnico di Milano, Milano, Italy
}

\begin{abstract}
A methodological similarity between Thomas Hobbes and Pëtr Kropotkin is the intention to elucidate a theoretical foundation to a broad audience, in the sense that they are willing to popularize a clear description of the reality and a subsequent political view. To do so, they use a scientific method, deductive (starting from empirical observations) in the case of Hobbes, inductive-deductive in the case of Kropotkin. Kropotkin also underlines the educational value of the scientific method. Although they both start their argumentations from a materialist ontology, Hobbes and Kropotkin conjecture two completely different states of nature. Hobbes describes the state of nature through the two famous metaphors homo homini lupus and bellum omnium contra omnes, while Kropotkin introduced the theory of mutual aid. Hobbes has been influenced by the scientific revolution initiated by Francis Bacon, one of his mentors, and Galileo Galilei. Kropotkin has been influenced by the ground-breaking writings of Charles Darwin together with a very fruitful Russian scientific environment. The disenchanted view of the human nature in Hobbes, a state of war due to the fact that everyone has rights on everything, helps him to legitimate sovereignty, while the positive view of human nature in Kropotkin, a spontaneous mutual aid among people in a community, helps him to legitimate anarchy. Therefore, the fascinating scientific methods of the two materialists Hobbes and Kropotkin to structure a solid political theory cannot neglect different views on human nature due to their historical contexts.
\end{abstract}

Keywords: Materialist philosophy; State of nature; Mutual Aid; Hobbes; Kropotkin

\section{Introduction}

The strength of the philosophy of Thomas Hobbes (1588-1679) and the philosophy of Pëtr Kropotkin (1842-1921) is the capability to conceive 
from the characteristics of nature a consequent Ethics and Politics. Hobbes deduces a state of nature, while Kropotkin employs an inductive-deductive method (Kinna, 1995). Both Hobbes and Kropotkin develop their philosophical systems within two scientific revolutions: Thomas Hobbes was fellow-philosopher and friend of Francis Bacon (1561-1626), the father of the modern scientific method, and was also influenced by Galileo Galilei (15641642) (Altini, 2019); Kropotkin was strongly influenced by Charles Darwin (1809-1882), perhaps the most revolutionary scientist of the nineteenth century that, with the contribution of Alfred Russel Wallace (1823-1913), has introduced the scientific theory of evolution.

The state of nature is a hypothetical human condition that did not necessarily exist in the human history. The conception of the state of the nature has been developed also by other philosophers, such as John Locke, JeanJacques Rousseau and Immanuel Kant. An interesting analysis of the state of nature, focussed on a parallelism between Hobbes and Kant, has been reported by Amer N. Shatara (Shatara, 2016). Focussing on the concept of state of nature, Shatara states that philosophers have employed such concept, according to their philosophical systems, with different functions. The state of nature can be employed to legitimate a certain political theory, or it can be exploited to corroborate some empirical observations on human nature (Shatara, 2016).

In this work, a parallel description of the conception of the state of nature by Thomas Hobbes and the conception of the theory of mutual aid by Pëtr Kropotkin is presented. This parallelism highlights the common ground of a materialist view of Hobbes and Kropotkin that lead to two completely different portrayals of the human nature, stressing their attempts to follow rigorously the scientific methods developed in the seventeenth century and the nineteenth century, respectively.

\section{The State of Nature in Hobbes}

The main point of the philosophy of nature of Thomas Hobbes is that everything is matter. In Leviathan Hobbes writes:

[...] the universe, the whole mass of things that are, is corporeal, that is to say, body, and hath the dimensions of magnitude, length, breadth and depth. Every part of the universe is 'body' and that which is not 'body' is no part of the universe, and because the universe is all, that which is no part of it is nothing, and consequently nowhere. (Hobbes, 1651)

In this mechanistic framework living beings, objects and even thoughts are 'bodies'. It is worth noting that this materialism does not rule out a reconciliation with Christianity and, in general, the supernatural, as 
highlighted by Okada (Okada, 2019). Moreover, it is interesting the account of M. P. Adams in which Hobbes borrows causal principles from geometry to reasonably describe bodies in the real world (M. P. Adams, 2016).

Hobbes deduces his anthropology from his materialist view, in which the vital movement of an animated body tends to self-preservation, with a rigorous mechanistic description. In the universe there are just bodies and the motion of these bodies. In this framework, man is a mechanism and from the motion man feelings. Men subjectively feel such perceptions as good or evil, but the supreme evil is death (and peace is the supreme good) (Chevallier, 1949). In De Cive Hobbes writes 'for every man is desirous of what is good for him, and shuns what is evill, but chiefly the chiefest of naturall evills, which is Death' (Chapter I, paragraph VII) (Hobbes, 1642). Moreover, everyone has rights to everything (ius in omnia) and, consequently, the action of a person will unavoidably conflict with the actions of other people.

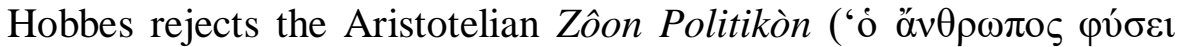

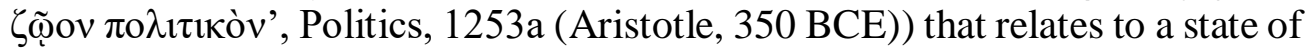
nature in which men are political, and social, animals. The state of nature in Hobbes can be defined as 'bellum omnium contra omnes' (Hobbes, 1651), an everlasting state of war when everyone is involved and that leads to a 'continual fear, and danger of violent death' (Hobbes, 1651). Thus, according to Hobbes human being is not constituted by social animals, but by men that want to avoid death (Donaldson, 1978). Self-preservation is the smallest common denominator that allows men to find a way to live together (Lemetti, 2010).

The conception of the state of nature in Hobbes, according to Shatara, does not have an origin from historical readings and it does not have an origin from a scientific analysis of nature (Shatara, 2016). Although, if Shatara properly states that such state of war is a hypothetical theory that arises from Hobbes conclusions on human nature (Shatara, 2016), this argumentation can be integrated: The human nature is the empirical observation that supports the aforementioned deductive method of Hobbes. In fact, the Hobbes' theorizing of the social contract for Shatara does reflect his experience of the political turmoil of the seventeenth century (Shatara, 2016). Hobbes is significantly influenced by the English Civil War (1642 - 1651). The English Civil War is a powerful evidence of the instinctive and brutal human nature and such instinctive human behaviour is the empirical observation of Hobbes. According to Chevallier, Hobbes has been also influenced by his readings of Greek philosophers such as the sophists, which have shed light on the brutality of human nature (Chevallier, 1949).

To briefly describe how Hobbes suggests to avoid the state of war, people should accept a contract that includes a Pactum unionis (or societatis), with which men constitute a society, together with a Pactum subiectionis, with 
which they delegate the power to a sovereign authority (Chevallier, 1949). Sovereignty pledges self-preservation and pledges a place for industry, arts and letters (Hobbes, 1651): Since people do not have to continuously fight each other, they can develop a society and spend time on disparate interests. The mythologic beast Leviathan, the Hobbesian metaphor of the sovereignty, defeats the mythologic beast Behemoth, the Hobbesian metaphor of the civil war. In Book of Job (Chapter 41), Leviathan is an extremely powerful beast (as also Behemoth) (Bible Gateway Passage, n.d.), while in Hobbes' Leviathan is an 'artificial man' (Chevallier, 1949) composed by the men that accept the contract (as depicted in the famous frontispiece of Hobbes' Leviathan). Leviathan is the artificial man, the body, and the sovereignty is the artificial soul that gives 'life and motion to the whole body' (Hobbes, 1651). The contract between the sovereignty and the people is thus the solution that Hobbes describes in Leviathan to overwhelm the state of war. Hobbes, as Machiavelli, has a disenchanted view of human nature and power. Although, Hobbes goes beyond Machiavelli, since Hobbes understood the crucial importance of law, and subsequently the importance of the contract, influenced by Middle Age theologists and eminent politologists such as Jean Bodin (Baumgold, 2010).

Hobbes, with the publication of De Cive in 1642 and Leviathan in 1651, defines himself as the inventor of civil philosophy (M. P. Adams, 2019). This claim can be explained by the fact that Hobbes intends civil philosophy as science. On one hand, the deductive method in Hobbes draws inspiration from Euclid and attempts to have the 'definitional' argumentation of the Euclidean geometry (M. P. Adams, 2019). But on the other hand, the context of Hobbes' endeavour should be taken into account. In 1543 Nicolaus Copernicus publishes the De revolutionibus orbium coelestium that includes the heliocentric theory, supported by the three laws of Johannes Kepler (1619). Galileo Galilei publishes in 1610 the Sidereus Nuncius, the first treatise based on observations made with a telescope, and in 1632 Dialogo sopra $i$ due massimi sistemi del mondo (Dialogue Concerning the Two Chief World Systems), laying the foundations for the scientific revolution. Hobbes has acted as secretary and amanuensis to Francis Bacon in the period in which Bacon was finishing the Novum Organum (1620).

\section{The Mutual Aid in Kropotkin}

After several important figures of modern anarchy, such as Willian Godwin (1756 - 1836), with the accent to individual autonomy, Pierre-Joseph Proudhon (1809 - 1865), theorist of libertarian socialism, Michail Bakunin (1814 - 1876), with the collectivist anarchism, and Errico Malatesta (1853 1932), with the revolutionary anarchism, it is worth noting the endeavour of Pëtr Kropotkin in giving a scientific background to anarchy. Following 
Mirella Larizza Lolli (Larizza Lolli, 2010), Godwin, Proudhon and Bakunin are the most significant contributors on anarchy as a political theory before Kropotkin. William Godwin has described government as a 'exertion of force' (Godwin \& Philp, 2013) that does not allow the proper development of reason of the people. Godwin counterposes to the state the small communities where everyone has the right and the obligation of participation. Pierre-Joseph Proudhon criticizes the contract related to the Pactum unionis/Pactum subiectionis of Hobbes, since government is authority (Proudhon \& Robinson, 2004), but Proudhon also criticizes the general will of Rousseau, since the contract should not have a general value. The contract in Proudhon should be signed only among individuals according to their needs. For Bakunin the state is an abstraction that should rejected by men. The man, with the own reason, should understand to follow natural laws, without the imposition of an 'extrinsic will' (Bakunin, 1970).

Concerning the theory of mutual aid developed by Kropotkin, it is fundamental the study by Ruth Kinna Kropotkin Theory of Mutual Aid in Historical Context (Kinna, 1995). Kinna stressed that Kropotkin understood that anarchism needed a solid theory with a strong scientific foundation. Moreover, Kropotkin argued that the educational value of science diminished over time because of a methodological specialization, with an 'inductivedeductive' method for natural science and a 'metaphysical' method for human sciences. Thus, Kropotkin suggested to avoid in separating natural and human science, as ancient Greeks did, and to adopt 'a conception of the Universe based on the mechanical interpretation which comprises the whole of Nature, including the life of all human societies and their economic, political, and moral problems' (Kropotkin, 1893). Biological research was for Kropotkin the starting point for the development of his theory of mutual aid.

Kropotkin has been influenced by Russian biologists, such as Severtsov and Kessler (who has been the first to introduce the concept of mutual aid (Barnard, 2004; Kinna, 1995)), that criticized Charles Darwin because of his assimilation of Malthus' argument that the increase of the population would always overtake the amount of means of subsistence. Moreover, the definition of 'struggle' introduced by Darwin and further developed by T. H. Huxley, in particular in the essay The Struggle for Existence (Huxley, 1894) has been strongly criticized by Kropotkin. Ruth Kinna masterfully reports that Kropotkin has developed a more biological sense of mutual aid and a more ethical sense of mutual aid, in which it can be distinguished the biological sense of mutual aid that is the instinctive sense of cooperation, while the ethical sense of mutual aid has been developed by the habits which come from the biological practice (Kinna, 1995). Kinna stresses how the codes of behaviour, the sense of communal interest and even the language are elaborated by species through the cooperation (Kinna, 1995). 
To stress the experimental science approach of Kropotkin, the report the following paragraph of his masterpiece Mutual Aid: A Factor of Evolution (Kropotkin, 1902) is worth noting:

As soon as we study animals - not in laboratories and museums only, but in the forest and the prairie, in the steppe and the mountains - we at once perceive that though there is an immense amount of warfare and extermination going on amidst various species, and especially amidst various classes of animals, there is, at the same time, as much, or perhaps even more, of mutual support, mutual aid, and mutual defence amidst animals belonging to the same species or, at least, to the same society. Sociability is as much a law of nature as mutual struggle. (Kropotkin, 1902)

The suggestion is to collect empirical evidences in forests, prairies etc. For Kropotkin the mutual aid is thus a tendency in the human nature:

The mutual aid tendency in man has so remote an origin, and is so deeply interwoven with all the past evolution of the human race, that is has been maintained by mankind up to the present time, notwithstanding all vicissitudes of history. (Kropotkin, 1902)

More, the mutual aid is a tendency in the majority of the species: 'in the long run the practice of solidarity proves much more advantageous to the species than the development of individuals endowed with predatory inclinations' (Kropotkin, 1902). Thus, for Kropotkin the competition should be avoided: 'Don't compete! - competition is always injurious to the species, and you have plenty of resources to avoid it!' (Kropotkin, 1902).

The endeavour of Kropotkin to structure a theory that supports his anarchic political view, taking into account the historical and scientific context, is much deeper with respect to what is discussed here and it is a vivid subject in the contemporary literature (M. S. Adams \& Jun, 2015). Although, the approach of Kropotkin is certainly remarkable: A scientific method that starts from materialist building blocks to derive the conception of a benign community in which mutual aid allows the possibility to overcome sovereignty.

Kropotkin never refers to mutual aid as a state of nature and never refers mutual aid as a conception that is opposite to 'bellum omnium contra omnes' of Hobbes. This is because of the inverted role of the Hobbesian state of war and the mutual aid of Kropotkin: Hobbes legitimates the sovereignty because it prevents the state of war, while Kropotkin legitimates anarchy through the mutual aid because a community naturally cooperates and does not need sovereignty. Thus, the mutual aid, the spontaneous cooperation of a community, can be considered as the state of nature of Kropotkin, 
demonstrated by Kropotkin via a scientific inductive/deductive method. But it is not a hypothetical 'condition under which individuals lived prior to the existence of society' (Shatara, 2016).

\section{Conclusion}

Jean-Jacques Chevallier has written in the Preface of the Les grandes oeuvres politiques that the political theories need to take into account a description of human nature (Chevallier, 1949). The most influential philosophers that have developed a political theory have always conjectured, in fact, a picture of human nature in agreement with their philosophical systems. This work presents a parallel analysis on the conception of the state of nature by Hobbes and on the conception of the theory of mutual aid by Kropotkin. The common ground of a materialist philosophy in Hobbes and Kropotkin is highlighted in this parallelism that diverges in a fork in which the two thinkers are led to develop two completely different human nature portrayals.

The coherence and the success of the political theories of Hobbes and Kropotkin are not discussed here. As a matter of facts, the anarchy suggested by Kropotkin up to now has never been a solid and long-lasting form of societal arrangement. Although, the reports on the links between mutual aid and action research (Munn-Giddings, 2001) and on mutual as a concept for the Prisoners' Dilemma (Tazdaït et al., 2008) makes the theory of mutual aid still attractive also out of the political theorist community. Among the criticisms to Hobbes' political theory, the co-existence of mechanism and decisionism (Altini, 2019) needs to be taken into account: The sovereign can use either the 'mechanistic' law or the 'voluntaristic' decision, i.e. an extraordinary intervention that might safeguard the life preservation of the subjects (Altini, 2019). It is also remarkable that in literature there are interesting reports of Hobbes as a theorist of anarchy concerning the international relations among nations (Bain, 2015). These interesting studies are not considered in this study. However, it is important to mention the Hobbesian contract between the sovereign and the people in a society, that leads to a 'monopoly on violence' (Max Weber in Politics as a Vocation (Weber, 1946)): '[...] the modern state is a compulsory association which organizes domination. It has been successful in seeking to monopolize the legitimate use of physical force as a means of domination within a territory' (Weber, 1946). Such monopoly of violence, together with the division of powers, the other very successful theory that has been developed in particular by Locke (also Locke, as Hobbes, conjectures a state of nature that allows him to erect his political theory) (Waldron, 2013), Montesquieu (Waldron, 2013), and Hegel (Bobbio, 2009), is at basis of the modern state. 


\section{References:}

1. Adams, M. P. (2016). Hobbes on natural philosophy as "True Physics" and mixed mathematics. Studies in History and Philosophy of Science Part A, 56, 43-51. https://doi.org/10.1016/j.shpsa.2015.10.010

2. Adams, M. P. (2019). Hobbes' Philosophy of Science. In E. N. Zalta (Ed.), The Stanford Encyclopedia of Philosophy (Spring 2019). Metaphysics Research Lab, Stanford University. https://plato.stanford.edu/archives/spr2019/entries/hobbes-science/

3. Adams, M. S., \& Jun, N. J. (2015). Political theory and history: The case of anarchism. Journal of Political Ideologies, 20(3), 244-262. https://doi.org/10.1080/13569317.2015.1075263

4. Altini, C. (2019). Potere e potenza in Hobbes. La prospettiva meccanicistica tra filosofia naturale e filosofia politica. Scienza \& Politica. Per una storia delle dottrine, 31(60). https://doi.org/10.6092/issn.1825-9618/9607

5. Aristotle. (350 BCE). The Politics vol. 1. https://oll.libertyfund.org/titles/aristotle-the-politics-vol-1--5

6. Bain, W. (2015). Thomas Hobbes as a Theorist of Anarchy: A Theological Interpretation. History of European Ideas, 41(1), 13-28. https://doi.org/10.1080/01916599.2014.948288

7. Bakunin, M. A. (1970). God and the state. Dover.

8. Barnard, A. (2004). Mutual Aid and the Foraging Mode of Thought: Re-reading Kropotkin on the Khoisan. Social Evolution \& History, 3(1), 3-21.

9. Baumgold, D. (2010). Contract theory in historical context: Essays on Grotius, Hobbes, and Locke. Brill.

10. Bible Gateway passage: Job 41 - New International Version. (n.d.). Bible Gateway. Retrieved 18 January 2020, from https://www.biblegateway.com/passage/?search=Job+41\&version=N IV

11. Bobbio, N. (2009). La teoria delle forme di governo nella storia del pensiero politico: Anno accademico 1975-76.

12. Chevallier, J.-J. (1949). Les grandes oeuvres politiques. De Machiavel à nos jours. Librairie Armand Colin.

13. Donaldson, S. S. (1978). From the natural to the civil state: The evolutionary process as viewed by Thomas Hobbes, John Locke and JeanJacques Rousseau (Paper 415) [Master's Theses, University of Richmond]. UR Scholarship Repository.

https://scholarship.richmond.edu/cgi/viewcontent.cgi?article $=1422 \& \mathrm{c}$ ontext $=$ masters-theses

14. Godwin, W., \& Philp, M. (2013). An enquiry concerning political justice. Oxford University Press. 
15. Hobbes, T. (1642). De Cive. https://www.constitution.org/th/decive.htm

16. Hobbes, T. (1651). Leviathan. http://www.gutenberg.org/files/3207/3207-h/3207-h.htm

17. Huxley, T. H. (1894). Evolution and ethics and other essays. MacMillan \& Co.

18. Kinna, R. (1995). Kropotkin's Theory of Mutual Aid in Historical Context. International Review of Social History, 40(2), 259-283. https://doi.org/10.1017/S0020859000113227

19. Kropotkin, P. (1893). On the Teaching of Physiography. The Geographical Journal, 2(4), 350-359.

20. Kropotkin, P. (1902). Mutual Aid: A Factor of Evolution. McClure Phillips \& Co.

21. Larizza Lolli, M. (2010). Stato e potere nell'anarchismo (2. ed., riv. e aggiornata). Angeli.

22. Lemetti, J. (2010). Hobbes, Aristotle, and Human Happiness. https://helda.helsinki.fi/handle/10138/15343

23. Munn-Giddings, C. (2001). Links between kropotkin' theory of 'mutual aid' and the values and practices of action research. Educational Action Research, 9(1), 149-158. https://doi.org/10.1080/09650790100200144

24. Okada, T. (2019). Hobbes on the supernatural from The Elements of Law to Leviathan. History of European Ideas, 45(7), 917-932. https://doi.org/10.1080/01916599.2019.1642003

25. Proudhon, P.-J., \& Robinson, J. B. (2004). General idea of the Revolution in the nineteenth century.

26. Shatara, A. N. (2016). On the Hypothetical State of Nature of Hobbes and Kant; Same Premises, Different Conclusions. European Scientific Journal, ESJ, 12(23), 209.

https://doi.org/10.19044/esj.2016.v12n23p209

27. Tazdaït, T., Caparros, A., \& Péreau, J.-C. (2008). Mutual Aid: An Indirect Evolution Analysis. https://halshs.archives-ouvertes.fr/halshs00275386

28. Waldron, J. (2013). Separation of Powers in Thought and Practice. Boston College Law Review, 54(2), 433.

29. Weber, M. (1946). Politics as a Vocation. In From Max Weber: Essays in Sociology (Oxford University Press, pp. 77-128). H.H. Gerth and C. Wright Mills. http://fs2.american.edu/dfagel/www/Class\%20Readings/Weber/Politi csAsAVocation.pdf 